\title{
REVIEW I Black Popular Music in Britain since 1945
}

Jon Stratton and Nabeel Zuberi Eds.

Surrey: Ashgate, 2014

ISBN: 978-1409469131(HB)

\author{
tobias c. van Veen \\ California State University, Northridge \\ tobias.vanveen@csun.edu
}

Providing a rich historical overview of black popular music in Britain after the Second World War, this collection focuses on the formative role of Afrodiasporic immigrants in shaping the shifting and contested terrain of what may be termed "British" music, from jazz and swing through to reggae, dub, postpunk, and lovers rock, before closing out the twentieth century with the advent of electronic music and its blacktronic variants of acid house, techno, jungle, and hardcore. The volume shifts from opening approaches grounded in ethnomusicology to later forays that read musical scenes, spaces, soundings, and styles for their cultural resistance and collective identity — or lack thereof.

The identity of British music is contested from the start with chapters that focus upon the post-War return of postcolonial nationals to the centre of Empire, particularly immigrant musicians from the West Indies (14). What might be termed "British" musicking is intimately bound-up with ethno-nationalist myth-making, arguably foreshadowing the neoreactionary politics of Brexit. Prevailing white 
fragility remains troubled by the arrival of immigrants who lay claim to Britishness in their identity. As both Hillegonda Rietveld and Jeremy Gilbert argue, British music has often been signified in the music press by way of default whiteness. In the 1990s, Britpop bands such as Blur and Oasis were seen as representing British music in a way that blacktronica was not. As contributor Mykaell Riley - also a founding member of British reggae group Steel Pulse — points out: "Black British music' was at best marginalized as a pale imitation of the American or Jamaican format," at least until jungle burst onto the scene, only to be "tamed, subsumed into club culture and repackaged and marketed as dance music" (111-12). The marginalization of black British music remains a refrain throughout this volume. But just as the nationalist signifier of "British" denotes a site of instability, editors Jon Stratton and Nabeel Zuberi state that "black music is not a fixed category" (5). Though the chapters in the collection demonstrate the concrete ways in which racialized identities are constructed in the cultural interplay of musicking - the rich forms of musical and paramusical processes in scenes, spaces, styles, soundings - their authors take care that the epidermalized descriptor of "black music" does not denote an essentialized sonic substance of the Other; for it is just as often that nontraditional (and Afrofuturist) blackness goes unrecognized, and is thus erased from the record.

Catherine Tackley's opening chapter addresses the contingencies and structural racism of such historical erasure. Turning to the West Indian Dance Orchestra, Tackley analyses public reportage, music trade publications, and black oral archives to contextualize how the orchestra rose to prominence as an "authentic" purveyor of jazz, authentic insofar as "blackness became increasingly understood as a marker of jazz authenticity" (13) during an era when government restrictions against American bands, and discrimination against African American performers, led to a lack of supply (14). By contrast, West Indians were not subject to government restrictions, nor conscription (15). Promoted by the BBC as "ultramodern dance music," the orchestra incorporated the latest in "American popular music [and] swing" (15), while also reflecting, for a brief time, a cultural space of "integration" that included "mixed race" venues such as recording studios and Rhythm Clubs. Yet there remained "active discrimination against black musicians," particularly from the "management of the upper-class venues" (19). Tackley unpacks the class dimensions of British identity by addressing the racialized politics of the First English Public Jam Session, a 24-member jazz supergroup whose members, including five from the orchestra, were voted in by fans (18). As Tackley notes, it is ironic that while the concert was seen as validating British jazz, the popular music media ignored the fact that "many of the musicians were from the wider British Empire" (and that two were Dutch) (18). Having "stood in" for African American musicians, West Indian jazz players "had a complex dual insider/outsider status," as both authenticators of British jazz while remaining, at the same time, "novelties" (26). Unfortunately, the orchestra, as a could-have-been milieu of 
diasporic blacknesses, did not survive the War. Two of its members, including bandleader Ken 'Snakehips' Johnson, died on stage as a bomb from the Blitz hit London's Café de Paris in 1941.

To a large extent, the neither/nor supplement of nonwhite British musical identity - as inauthentic purveyors of authentic nonwhite music imported from elsewhere - remains the framework of black music in Britain for the remainder of the century. In the British class system, blackness operates as supplement to static categories of white colonial identity - excluded but necessary. These latter hierarchies are confounded by the call-and-response milieu of Afrodiasporic genres and styles that Paul Gilroy (1993) has memorably termed the "black Atlantic." The black Atlantic is often concretized into specific immigrant neighbourhoods, forming what Hyder sees as essentializing discourses of the "music city" that produce a "homogenised model of cultural/musical development" (86). From clubs to cities to festivals, and as Rietveld, Hyder, and Gilbert point out, containerized spaces often give rise to constraining discourses for musical styles that likewise police the boundaries of ethnic identity. Countering such discourses is the "inter-ethnic exchange and syncretism" of artists like Tricky who upend, yet represent, the "continuity and change" of the Bristol Sound through musical styles and belongings that highlight "the constantly shifting nature of ethnic and cultural self-expression and identity" (86). The same can be said, perhaps, for Henriques and Ferrara's observations of the shifting styles of the Notting Hill Carnival, even as Notting Hill itself symbolizes certain expectations of ethnically-coded sound.

Genres, likewise, constrain ethnic codes to the gender expectations of patriarchy, as detailed by Lisa Amanda Palmer in her critical re-appreciation of the political gravity of lovers rock. Dismissed by artists such as Peter Tosh for its failure to communicate the "truth[s]" of "radical conscious roots reggae," lovers rock is set-up in opposition to "the decolonising politics of roots and culture" reggae from the 1970s (116). The result, argues Palmer, is that lovers rock is coded as feminine and apolitical while political agency is reserved for "militant" and thus masculine genres; thus "the process of gendering lovers rock reinforces the notion that erotic politics are inherently disconnected from the politics of protest" (117). By intersecting gender with genre, Palmer adds an important, and necessary, layer of feminist analysis to the codings of what we might call the structural racism (in its heteronormative white capitalist patriarchy) of British musicking that is, at its core, "a transatlantic musical form... that blended and borrowed heavily from black transnational cultural networks" (120). Palmer argues that "reconcil[ing] the dichotomies between the erotic and protest" (and thus reconfiguring expectations of both) leads to "complex outcomes for black male and female subjectivities" (117) - including a critical reappraisal of how "black masculinities are constructed outside of the politics of love" (a point Palmer draws from bell hooks) (122). Palmer's outstanding chapter suggests again the complex analysis, and value, of syncretism in black popular music studies, insofar as dichotomies must be defused 
with blending, merging, and differentiation, of not just tracing the criss-crossings of the Afrodiaspora but the intersectionality of gender and genre.

The syncretic, then, remains a tool to cut through such overcodings. Jon Stratton broaches the "50s and "60s with a few "syncretic... moments of intersection that forecast later developments" (28). I read Stratton as retroactively suggesting that Tackley's focus on the West Indian Dance Orchestra is one such syncretic moment, forecasting the supplemental inclusion/exclusion of blackness to Britishness. Stratton undertakes a syncretic approach to avoid the compartmentalization of black music "from the point of view of the dominant culture - that of 'white' Britain" (27). Yet the "specificity of black British popular music," argues Stratton, is revealed in the moments whereby "connections across different cultures... have the potential to remake musical forms" (28). Stratton argues that identity arises from the synthesis of such remaking of musical forms. Thus, it is in the mid-60s that "the foundation of an identifiably British black popular music can be found in the syntheses of black musics... from very different musical heritages" (28). Stratton's proof of the identitarian synthesis of black British music lies with the defenders of its newly minted canon. Stratton notes that "British jazz artists who supported the blues were often violently opposed to later developments in African-American music" (34), while, at the same time, African American artists (including Jimi Hendrix) were "attracted" to Britain because of "the perceived lack of racism" (34). Yet such racism was all too apparent in what Stratton describes as "subtle" attempts to constrain black musical forms as static and unchanging. While styles could not be contained, audiences could be. In the Madchester scene of the mid-1980s, Rietveld notes that many electro music fans mostly(but not all) black, were excluded from the Hacienda through the imposition of a dress code that banned sneakers suggesting how black identity is also materialized (and commodified) as an identifiable fashion.

Whether deploying concepts of synthesis, articulation, or (nouveau) materialism, what the approaches here have in common is that which takes form in a local milieu blows in from the crosswinds of the black Atlantic and reconfigures whatever it touches wherever it congregates - an argument likewise pursued by Robert Strachan, who characterizes the black Atlantic as inscribing "dual local and diasporic formal traits" through its "transnational flows" (67). Arising from the crossroads, then, is the significance of "sounding", as explored by Julian Henriques and Beatrice Ferrara at the Notting Hill Carnival. At Carnival, parade routes are territorial roots, places are pathways (150). The distinction of space to place, drawn from human geography, is crucial for popular music studies in thinking festivals and events that encapsulate soundings from elsewhere/when, whereby the "extensification of sounding along the parade route... contrasts and compliments the intensification of space through sound" through high-volume, bass-heavy sound systems (151). At Carnival, the extensive space/time flows of the black Atlantic intensify a place, for a duration (143), during which sound becomes a weapon and 
an experience of pain/pleasure (145). The result is an experience of "comingtogether or centripetal concentration of cultures" which Henriques and Ferrara generalize to "the British music scene more generally," as arising from the "specifically British diaspora that Carnival embodies" (152).

What is to be made of the distinction implied above by Henriques and Ferrara between the (black) "British diaspora" and the Afrodiaspora? Strachan observes that black Atlantic "hybrid expression[s] of identity" risk undermining black British identity, a point he draws from late '70s and early '80s genre of Britfunk, which is seen by critics as a facsimile of American music genres (67). Indeed, charges of copying from the Americans abound throughout these chapters. Such critics, argues Strachan, miss how "soul and funk offered a sense of identity that was not directly part of a Caribbean heritage but rather an alternative form of black Britishness" (76). This latter point, that blackness is not homogeneous, resonates throughout the volume insofar as multiple authors critically reposition and re-read genres that were often dismissed, at the time of their reception, as derivative. In such instances, what Strachan calls "complex form[s] of cultural politics" and their "version[s] of diasporic cultural articulation" (69) often reveal, as in the case of Britfunk, "an imagined, almost utopian set of images of what a modern, multi-racial society could be" (83). Thus the copy is also an original image of the (ideal) black Atlantic itself. And Notting Hill Carnival, strangely enough, becomes an idealized site of the 'British diaspora'. Such observations should lead us, however, to attend to with care any apparent transparency (of the matter, of the scene, of history) that syncretic analysis offers.

Markus Coester returns to the role of hybridity (which Hyder dismisses for remaining but the synthesis of a dualism, 86), turning to the "Afro Trend" of the 60s and 70s that connected eastwards to the continent itself. Coester traces the development of several West African highlife band members who lived in Britain for formal musical training and international connections during the turbulence of decolonisation (48). In this personalized localization of the black Atlantic, "the British Afro trend was less mediated through recorded music than through live performances" (59) - an observation that remains crucial to studies that grapple with the impact of festival culture, even if it points to yet another set of those "subtle" racisms that kept "very impressive" live stage performances from being recorded. Coester turns to Osibisa as a band who played off/in stereotypes of black styles, suggesting that Osibisa "may have actively promoted" the "juggling and subverting" of West African music that was at the "rhythmic source of most pop music," even if the latter claim (though well-meaning) remained a "media stereotyping" that had been surpassed, in any case, by "sophisticated modern styles like highlife" (60). Thus, for many European music audiences and critics, Osibisa "came to represent... African music outside of Africa" (62), even if, as Coester argues, "it was in Tunisia that Osibisa's musical approach and sound were born" (63). Critical media studies, in this respect, is indispensable to informing popular 
music studies, by pointing out how stereotypes are shaped in prevailing reportage and then played with by musicians themselves - in this case a band with a complex relationship to the decolonial project of the pan-African movement. And, like other blacknesses in Britain, the band branded as the "African future of pop" relied upon "West Indian musical expertise" (64). As Coester remarks, "this suggested that 'Peace and Black Brotherhood', the well-wishing and highlypropagated cultural politics, the self-assigned anti-colonial stance in Osibisa's early stage had proved harder to achieve than expected" (64). Here, a modern Afrodiasporic sound (highlife) is played against its stereotype ("African music") only to bear witness to its parallax.

Coester's comment is also suggestive of what Jeremy Gilbert argues concerning the "persistent lack of any political orientation" of black British electronic music as it manifests in the jungle and grime of the "hardcore continuum" (182). In a chapter that brings to bear the full weight of Deleuze and Guattari's (2000) critical analysis of cultural politics under capitalist "apparatuses of capture", Gilbert measures the sociopolitical impact of a genre that has been theorized, since its inception, as something much more than a mere musical form, but a posthuman formation capable, at least according to Kodwo Eshun (1999), of reformulating the ontopolitical stakes of blackness. Tempering the enthusiasm of Henriques and Ferrara, Gilbert concludes that, upon reflection, the forceful sounding of $1990 \mathrm{~s}$ jungle and the hardcore continuum is "an extraordinary site of sonic creativity entirely cut off from any political or social assemblage other than itself" (177). While the hardcore continuum brilliantly engaged in the "creative destruction" of black musical forms - for example, by sampling and speeding up AfricanAmerican hip-hop and funk into breakneck beats - its political economy remained caught up in all the pitfalls of immaterial labour (178). Thus while "innovative music scenes" are "always caught up in practices of commodity exchange," it "does not necessarily follow" they "are very closely integrated into processes of capital accumulation" (177), which is a nice way of stating a persistent paradox: that dedicated artists rarely set as their goal making enough money to change the industry (never mind capitalism). Innovative music scenes do not necessarily engender innovative economies - thus demonstrating, for Gilbert, that "creative autonomy in and of itself has very little political significance" (181), insofar as the political is, at base, economic.

Gilbert's argument does not necessarily confront the studies in the volume that celebrate how black musicking has reshaped British identity. Yet it is certainly at odds to Rietveld's reading of blacktronica artist A Guy Called Gerald's "Voodoo Ray [Rage]," which speaks to, among other things, how acid house and rave culture offered spaces of expressions for "black alienation" and the dis/utopian dreams of an "Afrofuturist coding" (164-5) that offer a "democratic ethos that cuts through class and ethnic divisions, inspiring a mixed-race subculture within the UK" (157). Of course, as Rietveld points out, democratic articulations of togetherness remain 
constrained by the fashion policings of clubculture (160) and are entwined with the spatial determinations of architecture (163). And, for Rietveld, democratic togetherness does not necessarily imply, as Gilbert would so dream and desire, an anticapitalist ethos.

Nabeel Zuberi, whose chapter follows Gilbert's, offers perhaps the most antithetical perspective, pointing out the role of the $M C$ in "a complicated story of creative enterprise flourishing in urban deprivation, institutionalized racism and struggles over 'voice' and representation for young black Britons" (186). The MC has a particular role to play as "reminders of black subjectivities" in a racialized world (191), and thus are able agents, or force-concentrations of voicing that embody forms and performances of resistance. While collective anti-capitalism might not be the outcome, representations of its dreams, particularly in an Afrofuturist mode, might be - and if it is one aspect noticeably absent from Gilbert's critique, it is the role of the radical black imaginary, Afrofuturism or otherwise, in potentiating future political action. Or as Zuberi sums up, "keeping it real may have changed" (195).

The authors in this collection all but say that racism remains as subtle as it is structural, and its ugliness arises in each decade. Gilbert's target remains the exuberance of 1990s hypertheory that saw in the hardcore continuum an ontopolitical fissure, and to this end, his critique cannot be ignored. But it also at times overstates the evident: that no one black musical genre can carry the weight of an anti-capitalist movement. Nor should it.

This volume demonstrates the complexity of articulating racism in each historical moment, providing tools, techniques, and examples to do so, and if anything, warns against theorizing the outcomes of how black popular music might shape the future of which it so often upends. Thinking that capitalism, even at a small scale, might be disrupted by diasporic music production is perhaps a thesis best abandoned to the previous century. Music is a force entwined with exchange value just as it is inseparable from the technologies of its distribution (and the digital mutations of the latter, if anything, have done more to upset previous systems of property). Instead, its politics are perhaps best thought in respect to their modelling of future utopias/dystopias, and its history conceived as an archive of futures yet-to-come.

\section{References}

Deleuze, G. and Guattari, F. 2000. A Thousand Plateaus: Capitalism and Schizophrenia. Translated by Brian Massumi. Minneapolis: University of Minnesota Press.

Eshun, K. 1999. More Brilliant Than the Sun: Adventures in Sonic Fiction. London: Quartet.

Gilroy, P. 1993. The Black Atlantic: Modernity and Double Consciousness. Cambridge: Harvard University Press. 